\title{
3. Keynes, the Keynesians and the exchange rate
}

One of the most quoted remarks in economics comes in the final chapter of Keynes's General Theory of Employment, Interest and Money, where he says:

the ideas of economists, both when they are right and when they are wrong, are more powerful than is commonly understood. Indeed the world is ruled by little else. Practical men, who believe themselves to be quite exempt from any intellectual influences, are usually the slaves of some defunct economist. Madmen in authority, who hear voices in the air, are distilling their frenzy from some academic scribbler of a few years back. ${ }^{1}$

Keynes believed that his book would be a particularly powerful 'intellectual influence' on such 'practical men'. He hoped that, by adopting his recommendations of increased state ownership and the counter-cyclical variation of public investment, the government would in future be able to prevent large swings in unemployment. He wanted to harness the fiscal powers of the state to make the trade cycle obsolete.

For about 25 years after the Second World War British economists thought that Keynes's ambition had been largely fulfilled. Of course, there were fluctuations in economic activity in the 1950s and 1960s. But these fluctuations, known as 'stop-go cycles', were mild by comparison with those in the inter-war period or the nineteenth century. Although unemployment varied in the course of the stop-go cycle, it never - even at the most immobile point of the 'stop' - amounted to more than a fraction of what it had been in the 1930s. This improvement, the so-called 'Keynesian revolution', was taken to be the triumph of modern economic theory over a number of ancient financial prejudices, notably the doctrine that the government should balance its budget. In the late 1960s no British economist expected the next 25 years to see large cyclical fluctuations in economic activity. The trade cycle may not yet have been obsolete, but it was thought to have depreciated to the point of insignificance.

Unhappily, these expectations were to prove wrong. The next 25 years were to see three major cyclical episodes. The first was the Barber boom of 1972 and 1973, followed by the severe downturn of 1974 and 1975; the second, from early 1978 to mid-1979, could be called the Healey boomlet, 
and gave way to the recession of 1980 and early 1981; and the third was the Lawson boom of mid-1986 to mid-1988, which preceded the recession of 1990 to 1992 . These episodes were not as extreme as the slump of the early 1930s, but they were comparable - in the amplitude of the fluctuations and other characteristics - to the trade cycles of the nineteenth century. They were certainly more noticeable than the stop-go cycles of the immediate post-war decades. The questions arise, "why did these large cyclical fluctuations come back?', 'what mistakes were governments making?' and 'were their mistakes tactical and accidental in nature, or the result of a strategic misunderstanding of how the economy works?' More pointedly, why did the madmen in authority behave as they did? And to which defunct economists were they listening?

In attempting to answer these questions the approach here will be largely historical. As we shall see, the reference to 'defunct economists' will not be purely rhetorical. The aim will be to consider why British economists, and hence the British government, were so unprepared for the problems of the 1970 s and 1980s. The underlying assumption is that events cannot be understood without an explanation - or at least an interpretation - of why people thought in the way they did. This essay will therefore be mostly an exercise in the history of ideas, particularly ideas about macroeconomic policy.

\section{I}

The notion of 'macroeconomic policy' is very modern. In the eighteenth century no one believed that the government had either the ability or the responsibility to manage the economy. Cyclical fluctuations in economic activity were sometimes pronounced, but these were regarded as acts of God like the weather or earthquakes. In particular, theorizing about the role of money in the trade cycle was rudimentary. In previous centuries the money stock had consisted entirely of metals, particularly gold and silver, and the quantity of money had therefore been determined by the past production of gold and silver mines. There had been little scope to substitute paper for these metals, because of the lack of trust in paper alternatives. However, as the eighteenth century wore on, Britain's political stability and the development of a satisfactory legal framework encouraged people to carry out an increasing proportion of their transactions in bank notes and bills of exchange. These paper instruments - whose validity depended on credit - came increasingly to perform the monetary functions of the precious metals.

But the growth of paper credit introduced a new risk. This was that the individuals and organizations issuing the paper alternatives to the precious 
metals might not be able to redeem them at their face value. A goldsmith banker might issue a note recognizing an obligation to repay the bearer on demand a particular weight of gold or silver, and the note might circulate widely and with perfect creditworthiness for many months or even years. But, if one of its holders presented it to the goldsmith banker and he was unable - for any reason - to pay over the stated quantity of precious metal, his entire note issue would fall into disrepute and this part of the money stock would no longer be able to circulate. Sudden collapses in the creditworthiness of paper lay behind some of the most severe cyclical fluctuations of the eighteenth century, even though precious metals continued to be the most important monetary asset. London bankers tried to anticipate the dangers by opening accounts and establishing a good relationship with the Bank of England, on the understanding that the Bank would act as a source of precious metals in an emergency. Country bankers in turn opened accounts and established good relationships with the London bankers.

The legislative response to these developments was twofold. First, restrictions were placed on the ability of private banks to issue notes, although these restrictions were surprisingly late in coming and were more a feature of the nineteenth than the eighteenth century. Secondly, the Bank of England - which was seen as the core institution from an early stage was required in successive Bank Charter Acts to redeem its note liabilities at a fixed price in terms of the precious metals. The price of gold was fixed at $£ 317 \mathrm{~s} 10^{1} / 2 \mathrm{~d}$ an ounce by Sir Isaac Newton in 1717 , while the first denominationalized notes were printed in $1725 .^{2}$ In other words, the Bank of England was mandated to protect a fixed exchange rate between its paper liabilities and the precious metals. After the Napoleonic Wars Parliament deprived silver of much of its former monetary role and established gold monometallism as the basis of Britain's money in 1821. Thereafter the essential features of Britain's monetary arrangements, and indeed the defining characteristics of the classical gold standard in this country, were the fixed gold price of $£ 317 \mathrm{~s} 10^{1} / 2 \mathrm{~d}$ an ounce and the ready convertibility of notes into gold and vice versa.

The logic of this system is easy to analyse and defend. Let us take it for granted that the public at large wants a money which is fairly reliable in terms of its ability to purchase non-monetary things. In this context precious metals have one key advantage as a monetary asset. Because they are highly durable, virtually all of the last period's stock of metals survives into the current and next periods. Further, as long as mining technology changes only slowly and there are no new discoveries, the production of new gold and silver in any one period should be only a small fraction of the stock of these metals accumulated over past centuries. As a result the 
stock of precious metals is very stable over time. Since it is therefore unlikely to increase more rapidly than world output, the price of commodities in general should be roughly stable in terms of the precious metals.

From this point of view, the introduction of paper alternatives to be precious metals is potentially dangerous. The production of paper money requires almost no resources. The quantity of paper money - unlike the quantity of precious metals - can be easily multiplied tenfold or a hundredfold. If this multiplication of the quantity of money occurs in a short period with no matching increase in output, the value of money is certain to collapse. Public policy could anticipate this problem by insisting that paper be convertible into gold at a fixed price. If the fixed exchange rate between paper and gold is maintained, and if the value of gold remains reasonably stable in terms of commodities, then the value of paper should also remain reasonably stable in terms of commodities. Here was the rationale for the gold standard in the nineteenth century. With paper anchored to gold at a fixed exchange rate the growth of paper money could not have systematic inflationary consequences

The gold standard was a success. Although the economy was subject to occasional cyclical disturbances and the price level varied both within these cycles and over longer periods, nineteenth-century Britain was a model of financial stability. Such was the admiration for Britain's achievement that by the 1880 s most other major industrial countries had also adopted gold as the basis for their monetary systems, creating the international gold standard of the late nineteenth century. The 'rules of the game' were well known. The central bank of every participating country had to preserve the convertibility of its note liabilities into gold at the agreed fixed exchange rate. The paper/gold exchange rate within each country implied certain exchange rates between the paper currencies of the participant countries. If an exchange rate came under pressure, the consequent external drain on the central bank's gold reserve had to be countered by raising interest rates. On the other hand, when a central bank's gold reserve was ample, it could cut interest rates. In the case of the Bank of England, its interest rate decisions were determined fairly mechanically by watching the proportion between its gold holdings and its deposit liabilities. $^{3}$ By the late nineteenth century its gold holdings varied mainly because of international pressures, rather than domestic changes in financial confidence. The practice of relating interest rate decisions to gold holdings and the exchange rate became deeply entrenched. The dependence of interest rates on international financial developments increased, even as the UK's weight in the world economy - and hence its share of the total world gold stock - diminished. 
But another and quite different approach to monetary policy would have been possible, and had indeed been intimated by some economists many years before. It would have relied on two revolutionary ideas which emerged in the debates on British financial policy during the Napoleonic Wars, debates which in their complexity and sophistication can fairly be described as the matrix of modern monetary theory. The urgency of those controversies arose because, under the strains of war, the Bank of England had been forced to suspend the convertibility of its notes into gold in 1797 . There was widespread public concern that the value of the notes, which continued to circulate as currency, would decline steadily. The vital question was how to stabilize the real value of the notes in the absence of the fixed anchor with gold.

The first of the two revolutionary ideas was that of the 'general price level'. Nowadays the concepts of an overall price level, of a price index which quantifies it and of an inflation rate measured by changes in the index are so commonplace that we rarely stop to think about them. That was not so in the 1790s. People were aware of the need to have a reliable monetary unit and standard of value, but they were not sure how best to formalize this need in precise numerical terms. Thus, when David Ricardo wrote about the depreciation of the currency in a famous pamphlet of 1810 he gave it the title, The High Price of Bullion, a Proof of the Depreciation of Bank Notes. He thought of currency depreciation in terms of the price of gold, not in terms of a general price level. However, there had already been innovators who had seen the potential for applying index numbers to the problem. According to Schumpeter:

A great step toward full realization of the importance of the method was made in 1798, when Sir George Shuckburgh Evelyn presented a paper to the Royal Society in which, with apologies for treating a subject so much below the dignity of that august body, he used an index number - of a primitive kind no doubt for measuring the 'depreciation of money'. ${ }^{4}$

The approach became progressively more refined in the course of the nineteenth century and in 1922 the American economist, Irving Fisher, published a monumental work on The Making of Index Numbers. One of the motives of this work - and, indeed, one of Fisher's strongest professional interests - was to define a price index whose stability would be the prime objective of monetary policy.

The second revolutionary idea, and perhaps an even more fundamental one, was to recognize that the nature of the inflationary process was radically changed by the introduction of paper money. With the functions of money increasingly being performed by paper instruments, the quantity of such instruments could affect the prices of goods and services. The link 
between the quantity of gold and its price had been the central interest of earlier monetary commentators. But, as more notes and bills of exchange entered the circulation, economists began to surmise that the connection might be between the quantity of all forms of money, both gold and paper, and the price level. The starting point for their analyses was the crude but serviceable principle that the greater the quantity of paper credit, the higher the price level. By extension, the higher the rate of increase in paper credit, the faster the rate of inflation.

The most impressive early work on these ideas was An Inquiry into the Nature and Effects of the Paper Credit of Great Britain by Henry Thornton, published in 1802. The timing of this great book, five years after the Bank of England's suspension of gold convertibility, was not an accident. Thornton was convinced that the widespread acceptability of paper in payments was an advantage to a country and, in particular, that it helped Britain to face wartime pressures on its economy.

Paper credit has . . . been highly important to us. Our former familiarity with it prepared us for the more extended use of it. And our experience of its power of supplying the want of gold in times of difficulty and peril, is a circumstance which . . may justly add to the future confidence of the nation. ${ }^{5}$

Nevertheless, Thornton was aware of the dangers inherent in a system of paper credit. He emphasized that an excessive issue of bank notes would lead to rises in the price level, while warning, on the other hand, that sharp contractions of the note issue could cause downturns in economic activity. His advice to the Bank of England was therefore to "limit the amount of paper issued, and to resort for this purpose, whenever the temptation to borrow is strong, to some effectual principle of restriction; in no case, however, materially to diminish the sum in circulation, but to let it vibrate only within certain limits' and 'to afford a slow and cautious extension of it, as the general trade of the kingdom enlarges itself' ${ }^{6}$

Here is the kernel of a new approach, the beginnings of the idea of 'monetary policy' or even 'macroeconomic policy'. Decisions on monetary management are no longer motivated by the gold price or an exchange rate between paper and a metal. Instead the central bank is understood to have fairly deliberate goals, to stabilize the price level and, as far as possible, to avoid large fluctuations in economic activity. Moreover, it is to achieve these goals by trying to control 'the sum in circulation' or, as we would now say, by regulating the money supply. This way of conducting monetary policy where the quantity of paper money is the target of central bank action - is clearly quite different from the earlier approach, with its focus on a particular gold price or exchange rate. ${ }^{7}$ 
Thornton's hint of a new style of monetary regulation was not taken up in his lifetime. On the contrary, the gold standard became established, gained increasing credibility and flourished until the First World War. But after 1918 another phase of intense monetary controversy began. The problem just as it had been after the Napoleonic Wars - was whether Britain should restore the gold standard at the pre-war parity.

The majority of bankers, politicians and so-called 'practical men' associated the gold standard with the stability and prosperity of the Victorian period. Perhaps without thinking very hard about the issues, they wanted to return to the gold standard. This point of view was expressed officially in the reports of the Cunliffe Committee, in 1918 and 1919, which said that restoration should occur as soon as possible. However, a small group of economists were sceptical, believing that the success of the gold standard in the nineteenth century had been largely a fluke and preferring a more deliberate and (as they described it) scientific approach to monetary policy. Their inspiration came from the great tradition of ad hoc and more or less amateur theorizing on the trade cycle in the nineteenth century, which had begun with Thornton and was developed in later decades by such authors as Tooke, Overstone, John Stuart Mill, Alfred Marshall, Bagehot and Hartley Withers. The theories were rather miscellaneous, but a common theme was that fluctuations in demand, output and the price level were driven by variations in the growth rates of credit and money.

The foremost sceptic about the gold standard was John Maynard Keynes. In his Tract on Monetary Reform, published in 1923, he identified the risk that gold could be kept in line with output only through chance discoveries of the metal. In any case, since Britain held only a small part of the world's gold stock, a return to the pre-war standard would leave it vulnerable to changes in other countries' demand for gold. There was no alternative to managing the currency:

If providence watched over gold, or if Nature had provided us with a stable standard ready-made, I would not, in an attempt after some slight improvement, hand over the management to the possible weakness or ignorance of boards and governments. But this is not the situation. We have no ready-made standard. Experience has shown that in emergencies ministers of finance cannot be strapped down. And - most important of all - in the modern world of paper currency and bank credit there is no escape from a 'managed' currency, whether we wish it or not; convertibility into gold will not alter the fact that the value of gold itself depends on the policy of the central banks. ${ }^{8}$

The answer, then, was not to go back to a fixed gold price, but to have a 'managed currency'. But how, in more specific terms, should a managed 
currency work? What objectives should policy-makers have and how should these objectives be achieved?

Keynes was clear about what he wanted. He was against not only the gold standard, but also a fixed exchange rate between the pound and the dollar, since this would leave Britain too much at the mercy of the American Federal Reserve. Although he recognized that 'an internal standard, so regulated as to maintain stability in an index number of prices, is a difficult scientific innovation never yet put into practice', that was nevertheless the ideal he favoured: 'I regard the stability of prices, credit and employment as of paramount importance.' ${ }^{9} \mathrm{He}$ referred with enthusiasm to Irving Fisher, as the pioneer of price stability as against exchange stability.

The Tract also devoted much space to the principles and practice of monetary management. In Keynes's view, 'The internal price level is mainly determined by the amount of credit created by the banks, chiefly the Big Five' and 'The amount of credit . . . is in its turn roughly measured by the volume of the banks' deposits'. ${ }^{10}$ There is a certain lack of clarity in these remarks, since it is not obvious whether it is the assets or liabilities side of banks' balance sheets that Keynes wanted to emphasize. But, if we agree that new lending creates deposits, this would be no great problem. The discussion of the mechanics of monetary control was also rather confusing. Keynes seemed to oscillate between two views, one that the size of banks' balance sheets is a multiple of their cash reserves, which can be determined by open-market operations, and another that 'adequate control' over an important part of banks' assets (that is, their advances and bills) 'can be obtained by varying the price charged, that is to say the bank rate'. ${ }^{11}$

But the technical complications should not be allowed to hide the essence of the 'managed currency' as Keynes envisaged it. The ultimate target should be the stability of the domestic price level, not the gold price or the exchange rate; and that target should be attained by managing the growth rate of banks' balance sheets, through interest rate variations if appropriate. It would be a matter of comparative indifference in practical terms whether the intermediate target here were taken as bank credit, bank deposits or a broad measure of the money supply, although the relevant pages in the Tract are a little muddled and ambiguous on the subject. It might also not add much to say that Keynes's managed currency had a certain amount in common with latter-day 'monetarism', since that begs the question of how monetarism should be defined. ${ }^{12}$ But there cannot be much doubt that - for most of his career - Keynes disliked having a fixed exchange rate as a policy target and paid close attention to credit and monetary variables when assessing economic prospects. That, on a careful reading of the texts, should be uncontroversial. 
At first Keynes's proposals for a managed currency got nowhere. Britain returned to the gold standard in 1925, with unhappy consequences for economic activity and employment, just as Keynes had expected. But after the departure from the gold standard in 1931, and the subsequent disintegration of international monetary order, Britain willy-nilly had the managed currency that Keynes advocated. Domestic objectives, not the gold price or the exchange rate, dominated policy-making in the 1930s. Until late in his career Keynes insisted that domestic objectives, not external, should have priority. In a speech on the proposed International Monetary Fund in the House of Lords in May 1943, he said:

We are determined that, in future, the external value of sterling shall conform to its internal value, as set by our own domestic policies, and not the other way round. Secondly, we intend to keep control of our domestic rate of interest. Thirdly, whilst we intend to prevent inflation at home, we will not accept deflation at the dictates of influences from outside. In other words, we abjure the instruments of bank rate and credit contraction operating through an increase in unemployment as a means of forcing our domestic economy into line with external factors. I hope your Lordships will trust me not to have turned my back on all I have fought for. To establish these three principles which I have just stated has been my main task for the last 20 years. ${ }^{13}$

It would be natural to assume that the post-war 'Keynesian revolution' would reflect the implementation of a macroeconomic policy directed to domestic priorities. That, indeed, is how some of the hagiographers have seen it. They have claimed that official policy in the first 25 years after 1945 was dominated by the aim of maintaining the domestic goal of full employment. Since a much closer approximation to full employment was achieved in these years than in the inter-war period, that may seem a reasonable assertion. However, monetary policy was certainly not organized in the way that Keynes had recommended in the Tract on Monetary Reform or in his May 1943 speech to the House of Lords.

On the contrary, the lodestar for interest rate decisions was the pound's exchange rate against the dollar. For 22 years, from 1945 to 1967, the pound was constrained by the Bretton Woods regime of fixed exchange rates and kept close to its central parity. (Admittedly, a big devaluation occurred in 1949 , but the $\$ 2.80$ rate was then maintained until 1967.) It was true that sterling's explicit link with gold had been broken and that the Bank of England did not redeem its note liabilities with any precious metal, as it had done before 1914. But the pound was tied to the dollar and the dollar was fixed to gold at the official price of $\$ 35$ an ounce. Britain may no longer have been on a formal gold standard, but sterling maintained a constant, if indirect and perhaps rather clandestine, relationship to gold for many years after Keynes's death. 
In these years of fixed exchange rates, academic and official interest in monetary policy dwindled steadily. Indeed, it could be argued that Keynes's General Theory was both the climax and the terminus of the nineteenthcentury tradition of trade-cycle theorizing, in which credit and money had been so important. Afterwards the overwhelming majority of British economists downplayed the significance of credit and money in macroeconomic fluctuations and inflation. There were at least three reasons for the new neglect of monetary analysis.

The first was that Keynes himself had been moving in this direction late in his career. At the time of the Tract he believed, with few qualifications, in the ability of interest rate changes to manage the currency and so to achieve desired macroeconomic outcomes. But in the 1930s very low interest rates were unable to prevent the persistence of high unemployment. One task of The General Theory was therefore to identify those circumstances in which low interest rates would be ineffective in stimulating investment and encouraging employment. He suggested that there could be a situation, a so-called 'liquidity trap', where people were so shell-shocked by the deflationary environment around them that they could not be induced to move out of cash into other assets. The deflation could not be countered by central bank action to cut interest rates. Keynes went on to advocate that the government take direct responsibility for investment in order to offset the possible impotence of interest rates. In his words, 'it seems unlikely that the influence of banking policy on the rate of interest will be sufficient by itself to determine an optimum rate of investment. I conceive, therefore, that a somewhat comprehensive socialization of investment will prove the only means of securing an approximation to full employment' ${ }^{14}$

This argument - linking the alleged ineffectiveness of monetary policy to wholesale nationalization - was one of the most influential and important in Britain's post-war political economy. In the 1950s and 1960s it gave economists a rationale both for a modishly left-wing sympathy towards state ownership, and for suppressing the teaching of monetary economics. It is very unlikely that this is what Keynes wanted. As the Tract made clear, a managed currency would have required a strong and detailed understanding of monetary institutions. Even The General Theory says far more about interest rates and monetary policy than it does about nationalization. But that Keynes contributed to the belittling of monetary economics, even of his own great work in the area, cannot be denied.

The second reason for the growing indifference towards monetary policy was that for almost 20 years, from 1932 to 1951, interest rates were virtually constant. Bank rate was held at 2 per cent throughout the period, apart from a brief (and insignificant) interruption at the beginning of the Second World War. Since hardly any interest rate changes occurred, there seemed 
little practical benefit in analysing the results of such changes. As interest rates had clearly not been much of an influence on business conditions for such a long period, economists thought they could ignore the possibility that interest rates might become important in the future. Even in the 1950s and 1960s interest rate variations were small for most of the time. In British universities theorizing about the effect of interest rates on the economy and so about monetary policy in the large - became moribund.

Thirdly, during the Second World War, and for many years afterwards, the British economy was subject to a wide variety of administrative controls of one sort or another. Rationing, conscription and the requisitioning of resources for the armed forces had a clear military function and could not be accepted for long in peacetime. But other restrictions - such as exchange controls, tight planning controls on building materials, controls on new issues and so on - survived long after the war had ended. Many civil servants and politicians thought that the economy could be run better by relaxing or tightening these controls than by relaxing or tightening monetary policy. Their ideal was not Keynes's 'managed currency', which would have been fully compatible with market capitalism, but a semi-socialist mixed economy with extensive economic planning. In the late 1940s and 1950s a large number of British economists undoubtedly welcomed the retention of controls and a commitment to planning.

If this seems a strong statement, it needs to be emphasized that 1963 saw the publication of an official document on Conditions for Faster Growth, which enjoined a more active government role in industry, with the full blessing of the then Conservative government. In 1964 the Department of Economic Affairs, with even more interventionist objectives, was established by the newly elected Labour government of Mr Harold Wilson. $\mathrm{Mr}$ Wilson had previously been an economics don at Oxford University and his government introduced large numbers of academic economists into Whitehall. It is a fair comment that none of these economists was much bothered by monetary policy, but all of them were fascinated - in one way or another - by the potential of 'economic planning'. One kind of control was particularly important in the monetary field, direct quantitative restrictions on bank lending. With credit kept under control by such means, the role of interest rates in macroeconomic policy was rarely discussed.

By the late 1960s hardly any British economist thought that interest rates could or should be varied to influence domestic economic variables. The immensely influential National Institute of Economic and Social Research never mentioned the money supply, on any of its definitions, in its Reviews. It only occasionally referred to credit variables and even then the focus was on hire purchase rather than mortgage lending. Whole volumes were written on macroeconomic policy with hardly any comment on money. For 
example, in a book on The Labour Government's Economic Record: 1964-70, edited by Wilfred Beckerman and published in 1972, there was only one index reference to 'the money supply', whereas there were 17 to the National Economic Development Council, 21 to the National Board for Prices and Incomes, and no less than 41 to the National Plan and 'Planning'. ${ }^{15}$ In the early 1970s the Cambridge Economic Policy Group was established with the support of such well-known figures as Lord Kaldor and Professor Robert Neild. The much publicized recommendations in its Economic Policy Reviews almost never contained remarks on monetary policy, unless they were dismissive. According to one article in its March 1977 issue, 'In our view there is no justification at all for incorporating a target for domestic credit expansion in official economic policy'. ${ }^{16}$ (As mentioned in the Introduction, and noted again below on p. 69 and in Essay 9, Neild was one of the organizers of the letter to The Times from the 364 which protested against the 1981 Budget.)

An extraordinary somersault had been accomplished. Whereas in 1923 the managed currency favoured by Keynes had seen the restraint over credit growth as central to monetary regulation, in the 1970s Cambridge economists and, indeed, most economists in British universities saw no merit in targets for credit and monetary growth. Many of them saw no point in analysing credit or monetary trends at all. Inflation was better understood, in their view, by watching the behaviour of wages and the exchange rate. The readiness of staff at the National Institute and the Department of Applied Economics to adopt the label of 'Keynesian' was the more remarkable in that it overlooked huge chunks of Keynes's own writing. These economists did not seem to appreciate that their ways of thinking were a betrayal of Keynes's ideas. Instead their loyalty was to second-rate textbooks which regurgitated, for decades after they had lost any practical relevance, the dangers of the liquidity trap and interest-inelastic investment.

The questions arise, 'how then was the Keynesian revolution accomplished?' and 'what were the techniques of economic policy which gave the British economy its stability in the first 25 years after the war?' If Keynes's managed currency was forgotten by most British economists, who or what should be awarded the medals for the relative financial tranquillity of the immediate post-war decades? It is here that we come to a yet greater paradox. There can be hardly any doubt that the key economic constraint on British governments in those years was the avoidance of sterling devaluation. Whenever policy-makers embarked on unduly stimulatory policies, the pound would come under downward pressure on the foreign exchanges and the resulting 'sterling crisis' would oblige the government to think again. It was the succession of sterling crises, and the need to check them by credit restrictions and/or higher interest rates, which kept inflation under control. 
Since the pound/dollar rate was the lynchpin of the system, American monetary policy determined British monetary policy. Fortunately, American monetary policy in the first 25 years after the war was a model of antiinflationary prudence and counter-cyclical stability. As Keynes had noted in his May 1943 speech to the House of Lords, 'the instruments of bank rate and credit contraction' would be dictated from outside Britain in a fixedexchange-rate system. But it was precisely these instruments which not only kept the UK price level in line with the world price level (of traded goods, expressed in terms of a common currency), but also delivered the full employment, low inflation and cyclical moderation of the post-war period. The exchange rate played a positive and benign role in British macroeconomic management. Keynes's suspicion of international financial influences on monetary policy-making proved misplaced.

Before we discuss what happened after the pound/dollar link was broken, another irony needs to be mentioned. American monetary policy in the first two decades after the Second World War was unquestionably a success compared with other periods, both before and after. But why? Many of the good decisions can be attributed, of course, to the professionalism of the staff of the Federal Reserve System and the budgetary restraint of Presidents Truman and Eisenhower. But there was another factor at work. One of the reasons for the Federal Reserve's tightening of monetary policy in the late 1950s was to protect the dollar on the foreign exchanges and, in particular, to preserve the $\$ 35$-an-ounce gold price. Gold was still the bedrock of the Bretton Woods system. Does it follow from this argument that the Keynesian revolution was not the result of the discretionary demand management and fiscal fine-tuning so much praised in the textbooks? Can the happy stability of the 1950s and 1960s instead be seen to rest on two fixed exchange rates, the $\$ 2.80$ rate between the pound and the dollar, and the $\$ 35$-an-ounce official price of gold? Was the prosperity of that period due not to the final abandonment of the 'barbarous relic', but rather to the UK's membership of the Bretton Woods system and the world's last inarticulate clinging to a gold anchor?

\section{III}

The two exchange rates were scrapped in the early 1970s. In August 1971 the American government suspended the dollar's convertibility into gold, because of the rapid decline in its gold reserve, while in June 1972 the pound left the embryonic European 'currency snake', after belonging for less than two months. Sterling's exit from the snake was to inaugurate a period of deliberate floating. We have already seen that one of the key preconditions 
for wise domestic monetary management - namely, a deep and extensive understanding of monetary economics among professional economists no longer existed in Britain. Very few academic economists were interested in the pre-Keynesian tradition of trade-cycle analysis, the acknowledged classics of monetary theory or contemporary monetary institutions. As a result there was no longer any heavyweight intellectual obstacle to rapid domestic credit and monetary expansion. The external barrier to inflationary policies, which had been imposed by a fixed exchange rate for over 20 years, was now also removed.

The scene had been set for the Barber boom of the early 1970s. There is little point in describing that boom in detail once more. Suffice it to say that credit and monetary growth were extraordinarily fast by any previous standards. But most British economists were unconcerned about the potential inflationary repercussions and instead celebrated the very rapid output growth from mid-1972 to mid-1973. (The level of GDP, at factor cost, expenditure based, was 8.6 per cent higher in real terms in the middle two quarters of 1973 than in the middle two quarters of 1972. Domestic demand grew even faster.) On 7 May 1973 Mr Peter Jay, the Economics Editor of The Times, wrote an isolated article entitled, 'The boom that must go bust'. The National Institute Economic Review judged in the same month that, 'there is no reason why the present boom should either bust or have to be busted'. The Review was undoubtedly representative of professional economic opinion.

Later it became uncontroversial that something had gone horribly wrong. The current account deficit on the balance of payments was a postwar record in 1974 and in mid-1975 the inflation rate hit 25 per cent. In 1976 Mr Healey, the Chancellor of the Exchequer, introduced money supply targets in order to establish a monetary framework for reducing inflation. These targets opened up the possibility that interest rate changes might be determined by the behaviour of monetary growth rather than by the exchange rate. The targets were expressed in terms of broad money, which is dominated by bank deposits. Broad money targets were to survive for almost a decade, until they were dropped in late 1985. Although the need for some kind of money target, or a so-called 'nominal framework', was widely accepted, it would be wrong to think that academic economists were much involved in its introduction. On the contrary, the case for money targets was urged most vigorously by City economists and in the financial press, notably in The Times. ${ }^{17}$

The heyday of broad money targets was in early 1980, only a few months after the Thatcher government had come to power. At about the same time as the announcement of the medium-term financial strategy in the Budget of that year, the government published a Green Paper on Monetary 
Control. It set out the rationale and the method of operation of broad money targets. In its words, 'The Government's policy is . . to sustain downward pressure on prices by a progressive reduction of the rate of growth of the money supply over a period of years' ${ }^{18}$ (This statement clearly implied that monetary growth caused inflation.) The reduction in monetary growth was to be accomplished partly by curbing public sector borrowing from the banks (which depended on the total amount of public sector borrowing minus sales of public sector debt to non-banks) and partly by discouraging bank lending to the private sector. Although sceptical that the private sector's demand for bank finance was responsive to interest rates in the short run, the Green Paper's aversion to quantitative credit restrictions left interest rates as the only instrument available to regulate credit expansion. It followed that interest rates were to be raised if monetary growth was ahead of target, but lowered if it was behind target.

In effect, the Green Paper on Monetary Control set out an approach to monetary policy which - in its emphasis on the credit counterparts to deposit growth and its focus on domestic rather than external objectives had clear similarities to Keynes's scheme for a 'managed currency' in the Tract on Monetary Reform. Moreover, in a number of speeches Sir Geoffrey Howe, the then Chancellor of the Exchequer, argued that the exchange rate had to be allowed to float if the government was to have the freedom over interest rates required to achieve its money supply targets. Interest rates were to be governed by domestic criteria, with a view to attaining price stability, rather than by the exchange rate.

The question of what happened to broad money targets, and the system of financial control associated with them, is not much debated now. There is hardly space here to provide a detailed history of British economic policy in the early $1980 \mathrm{~s} .{ }^{19}$ However, certain salient points are essential to the argument. In late 1980 monetary growth ran far ahead of target, obliging the government to keep interest rates high despite a deepening industrial recession. The exchange rate rose to remarkable levels and by early 1981 was clearly overvalued. Most economists, appalled by this turn of events, urged the government to ease the deflationary pressures. They wanted it to pay more attention to the exchange rate and less (or none at all) to domestic monetary trends.

But in the Budget of March 1981 the government raised taxes in order to keep public sector borrowing within the targets stated in the MediumTerm Financial Strategy. Two professors of economics at Cambridge Frank Hahn and Robert Neild - organized a letter to The Times from 364 economists at British universities, which claimed that the government's policies 'will deepen the depression, erode the industrial base of the economy and threaten its social and political stability'. The 364 economists 
were wrong. The British economy began to recover only a few months after it had been written and above-trend growth was maintained from late 1983 to 1989. (See the discussion about the 1981 Budget and its sequel in Essays 9 and 10, on pp. 181-229.)

But to assume therefore that the letter from the 364 had no influence would be a very serious mistake. It accurately reflected the overwhelming consensus of British academic opinion. Whenever officials from the Treasury or the Bank of England took part in academic conferences, both in these years and later, they were subjected to a barrage of scorn for obeying their political masters and implementing money supply targets. The constant sniping took its toll. Perhaps even more important, there was only limited academic interest in the technical operation of the system of monetary management actually at work in the early 1980s. A substantial literature developed on the merits of an alternative system of monetary base control, but this was not strictly relevant to the day-to-day problems facing the Treasury and the Bank of England. For example, whereas City newsletters and circulars discussed the problem of 'overfunding' in some detail in 1984 and 1985, it received hardly any comment in academic journals. The reason was simple. There were very few university economists who respected what the government was trying to do, namely, to combat inflation by reducing the rate of broad money growth. ('Overfunding' was the practice of selling more public sector debt to the non-bank private sector than the budget deficit, in order that the excess proceeds could be used to reduce the banks' claims on the public sector, and hence reduce both banks' assets and their deposit liabilities.)

So when broad money targets were scrapped in late 1985 there was general relief in university economics departments that, at long last, the government had returned to sanity. 'Sanity' was to be understood, in their view, as the former style of macroeconomic management with interest rate changes determined largely by the pound's fortunes on the foreign exchanges. The government nevertheless retained monetary targets, at least in form. Few people outside the Treasury took these targets, which came to be expressed in terms of narrow money rather than broad money, all that seriously. City commentators noted that the quantity of notes and coin, which is the main constituent of the officially favoured narrow money measure, M0, is determined by the current economic situation, rather than being a determinant of the future behaviour of demand and output. It followed from this that narrow money could not have any casual role in the inflationary process.

Keynes had, in fact, made precisely the same point in the Tract over 60 years earlier. He remarked that, in the circumstances of the early 1920s, 'Cash, in the form of bank and currency notes, is supplied ad libitum, that 
is in such quantities as are called for by the amount of credit created and the internal price level established'. It followed that: 'the tendency of today - rightly I think - is to watch and control the creation of credit and to let the creation of currency follow suit, rather than, as formerly, to watch and control the creation of currency and to let the creation of credit follow suit'. ${ }^{20}$ Keynes's preference for watching bank credit and deposits rather than currency (in the form of coin and notes) was partly a byproduct of his aversion to gold. Under the Bank Charter Act of 1844 the Bank of England had been required to restrict the fiduciary note issue (specifically, that part of the note issue not backed by gold holdings in its Issue Department) and gold had remained, in principle, the ultimate regulator of the quantity of notes. But Keynes wanted 'the volume of paper money' (that is, notes) to be 'consequential . . . on the state of trade and employment, bank rate policy and Treasury bill policy', so that the 'governors of the system would be bank rate and Treasury bill policy'. He therefore made 'the proposal - which may seem, but should not be, shocking - of separating entirely the gold reserve from the note issue'. If this were done, monetary policy would be free to serve the government's proper objectives, which in his view were, of course, the 'stability of trade, prices and employment'. ${ }^{21}$

The Treasury's adherence to M0 in the mid and late 1980s was halfhearted. Nevertheless, as Keynes would have expected, it had unfortunate consequences. Because it is an indicator rather than a cause of inflation, it failed abjectly to give advance warning of future inflationary trouble. The role of two self-styled 'monetarist' advisers to the government, Sir Alan Walters and Professor Patrick Minford, in this failure needs to be mentioned. In the early 1980s they were both critical of the importance attached to credit and broad money, and advocated that narrow money be given a more prominent role. Conservative politicians did not trust the great mass of left-leaning British academic economists, but they did consult the ideologically sound Walters and Minford. The advice of these two economists was therefore instrumental in undermining the framework of monetary management which was in existence before Mrs Thatcher and her Treasury ministers started listening to them.

In his book Britain's Economic Renaissance Sir Alan Walters observed that it is money in the 'transactions sense that plays the central role in the theoretical structure and the proposition of monetarism'. He gave paying a bus fare as an example of the kind of transaction he had in mind, and distinguished this sharply from 'credit'. (To quote, 'You pay your bus fare with money; you do not offer the fare collector a promissory note. ${ }^{22}$ ) But, whatever the role of money in this 'transactions sense' in either Walters's or the British government's understanding of monetary economics during the 
1980s, it had actually been superseded several decades earlier by the leaders of economic thought.

The whole point of Keynes's critique of classical monetary theory was that it overlooked the position of money in a portfolio of assets. If the demand to hold money rose for reasons of increased liquidity preference, the demand to buy goods and services would fall. In Keynes's extreme case of the liquidity trap, the ability of money's non-transactions role to expand indefinitely could become the jinx of the capitalist system. Hicks also saw the need to locate money in a framework of portfolio choice, proposing that the principle of marginal maximization should be borrowed from microeconomics. ${ }^{23}$ Friedman's attempt to restate the quantity theory related the demand for money to wealth, as well as income and other variables. ${ }^{24}$ Walters's neglect of these basic ideas, and their many implications, is further testimony to British economists' lack of insight into the role of credit and money in macroeconomic fluctuations. Walters and Minford agreed with the majority of Keynesian economists in British universities that Nigel Lawson, as Chancellor of the Exchequer, was correct to abandon broad money targets in late 1985. They were part of the extensive coalition of academic economists which regarded the monitoring of trends in credit and broad money as unnecessary.

\section{IV}

The sequence of events after the scrapping of broad money targets in 1985 had clear similarities to that after the abandonment of a fixed exchange rate in 1971 and 1972, except that the boom evolved somewhat more slowly. The focus of monetary policy again became the exchange rate. In late 1985 and early 1986, with the dollar falling rapidly on the foreign exchanges, the exchange rate did not signal a need for higher interest rates. The pound itself fell heavily in late 1986, particularly against the Deutschmark, but this was interpreted as a necessary and welcome result of lower oil prices. (In 1984 exports of oil had amounted to almost $£ 15$ billion, equivalent to almost 20 per cent of total exports of goods. The pound was widely seen as a 'petro-currency'.)

From March 1987 to March 1988 sterling was deliberately kept in a band of 2.95 to 3 against the Deutschmark. However, with German interest rates so much beneath those in Britain, this external factor argued for an easing, rather than a tightening, of domestic monetary policy. In effect, from late 1985 to early 1988 there was no meaningful external constraint on domestic monetary policy. The external environment allowed rapid growth of domestic credit and fast monetary expansion, just as it had after the ending 
of the dollar's convertibility into gold in August 1971 and the pound's exit from the European snake in June 1972. Interest rates fell, credit growth accelerated and the growth rate of broad money - no longer dampened by overfunding - also increased. By late 1986 the economy was undoubtedly growing at an above-trend rate. By mid-1987 it was in a full-scale boom. The mood of businessmen, particularly get-rich-quick property speculators, was an almost exact replica of that in the Barber boom 15 years earlier. Indeed, the bank lending and broad money numbers themselves were remarkably similar. (See Essay 14, on pp. 281-315, for further discussion.)

But did British economists, of either the Keynesian or narrow money schools, object? Did they warn that the boom would inevitably end in a worse payments deficit, a rising inflation rate and a need for a sharp cyclical downturn to offset the excesses of the boom? Sadly, it is hardly necessary to answer these questions. The clear majority of them - in the universities, the official policy-making machine and the City - raised no objections and issued no warnings. On the contrary, the consensus macroeconomic forecast in 1986, 1987 and early 1988 was that the economy was about to slow down to a trend rate of output growth without any rise in interest rates. (This tendency to predict a slowdown two to three quarters from the current quarter was so widespread and persistent that it became known as 'forecasters' droop'.) All of the so-called leading forecasting bodies - the London Business School, the National Institute, the Treasury and their many imitators - believed that the inflation rate in the late 1980s would be similar to, or lower than, that in the mid-1980s. ${ }^{25}$

Without an appropriately valued fixed exchange rate to guide interest rate decisions, academic economists were slaphappy about the mediumterm implications of grossly unsustainable domestic monetary trends. The indifference of academic opinion gave economic advisers in the civil service and the Bank of England a pretext for not alerting their political masters to the foolishness of policy. ${ }^{26}$ The Lawson boom of the late 1980s - like the Barber boom of the early 1970s - was the result of British economists' lack of recognition of how credit and money affect demand, output, employment and inflation. It was due, above all, to a great vacuum in intellectual understanding. The Lawson boom was followed, like the Barber boom, by a sharp rise in inflation and a recession. It therefore wrecked the greatest asset the Thatcher government had in the general elections of 1983 and 1987, a high reputation for managerial competence in running the economy and controlling inflation. These consequences can be fairly described as the revenge of the 364 .

However, there was no excuse for the vacuum in intellectual understanding. Keynes had set out over 60 years earlier in his Tract on Monetary Reform how a system of monetary policy focused on domestic objectives 
should work. The key intermediate indicators in the Tract were the growth rates of credit and bank deposits (or, as we would now say, broad money), just as they were in the original medium-term financial strategy declared in 1980. Keynes's agenda in the Tract should be seen as the logical culmination of many decades of analysis and theorizing about the trade cycle. This tradition of British monetary economics began with Thornton and Ricardo, and proceeded through (among others) John Stuart Mill, Bagehot and Alfred Marshall, to Keynes's contemporaries, Dennis Robertson and Ralph Hawtrey. But it withered and died in the 1940s and 1950s. It suffered, most of all, from the deliberate and ideologically motivated neglect of an economics profession far more interested in planning how a semisocialist economy might work in the future than in understanding how a free-market economy had operated in the past (and does now operate and will indeed continue to operate in the future).

The closing phase of the Lawson boom saw a vigorous debate between those economists who favoured membership of the European monetary system and others who wanted to maintain policy independence. As noted in the Introduction, the dominant position in the UK economics establishment - with its strong Keynesian leanings - was to support EMS membership. This was a bizarre twist, in two ways. The fixing of the exchange rate was not the currency regime endorsed in the great mass of Keynes's writings on the topic, while the effect of linking the pound with the Deutschmark was to subordinate UK interest rates to decisions taken by the avowedly monetarist Bundesbank. ${ }^{27}$ Indeed, if the UK had turned out to be a long-term participant in European monetary unification, it would have lost control of both monetary and fiscal policy. It is fair to ask, 'was this how "the Keynesian revolution" was supposed to end?' And, if one wants to find the 'defunct economists' to blame for the muddles and disasters of the 1970s and 1980s, is it not justified to suggest that the academic Keynesians - most of whom never paid much attention to Keynes's early work in the Tract - should be identified as the culprits?

In the event the pound joined the Exchange Rate Mechanism, a necessary period of apprenticeship in the full EMS, in October 1990. But it stayed inside the ERM for less than two years, enduring a recession far worse than the EMS advocates had envisaged. Comparisons were drawn between the decision to accept the exchange rate discipline of the ERM in 1990 and the decision to accept the exchange rate discipline of the gold standard in 1925, to which Keynes had so eloquently objected. The pound was expelled from the ERM on 16 September 1992 in circumstances of extreme international humiliation. The UK has subsequently both eschewed a fixed exchange rate link with any other currency and declined to participate in European monetary union. It has also - somehow - been 
able to run its own currency and economy with an impressive degree of stability, arguably on the lines of the 'managed currency' adumbrated by Keynes in his 1923 Tract on Monetary Reform. (The story of how this achievement should be interpreted is taken up in Essay 13.)

\section{NOTES}

1. D. Moggridge and E. Johnson (eds), Collected Writings of John Maynard Keynes, vol. VII, The General Theory of Employment, Interest and Money (London: Macmillan, 1973, originally published 1936), p. 383.

2. V.H. Hewitt and J.M. Keyworth, As Good as Gold: 300 Years of British Bank Note Design (London: British Museum Publications in association with the Bank of England, 1987), p. 27.

3. C.A.E. Goodhart, The Business of Banking, 1891-1914 (London: Weidenfeld and Nicolson, 1972), pp. 195-208.

4. J.A. Schumpeter, History of Economic Analysis (London: George Allen and Unwin, 1954), p. 256.

5. H. Thornton, An Enquiry into the Nature and Effects of the Paper Credit of Great Britain (Fairfield, NJ: August M. Kelly, 1978, reprint of version edited by F.A. von Hayek and published by George Allen and Unwin in 1939; originally published 1802), p. 276.

6. Thornton, Paper Credit, p. 259.

7. I am not suggesting that Thornton was opposed to the gold standard. In fact, his 1811 contributions to two House of Commons debates show that he was strongly in favour of it. See Paper Credit, p. 346. I am claiming only that his writings hinted at the possibility of a different approach.

8. Moggridge and Johnson (eds), Collected Writings of Keynes, vol. IV, A Tract on Monetary Reform (London: Macmillan, 1971, originally published 1923), p. 136.

9. Moggridge and Johnson (eds), Keynes, vol. IV, Tract, pp. 126-7 and p. 140.

10. Moggridge and Johnson (eds), Keynes, vol. IV, Tract, pp. 141-2.

11. Moggridge and Johnson (eds), Keynes, vol. IV, Tract, pp. 142-5.

12. I discussed some of the definitional problems in my contribution 'British and American monetarism compared', pp. 38-72, in R. Hill (ed.), Keynes, Money and Monetarism (London: Macmillan, 1989). (This paper is reprinted in this volume as Essay 7 on pp. 146-72.)

13. Lord Kahn, On Re-reading Keynes (London: Oxford University Press for the British Academy, 1975), pp. 22-3.

14. Moggridge and Johnson (eds), Keynes: General Theory, p. 378.

15. W. Beckerman (ed.), The Labour Government's Economic Record: 1964-70 (London: Duckworth, 1972), pp. 340-41.

16. F. Cripps and M. Fetherston, 'The role of monetary policy in economic management', Economic Policy Review, March 1977, p. 54.

17. Tim Congdon, Monetarism: An Essay in Definition (London: Centre for Policy Studies, 1978), pp. 11-13. See also chapter 6, 'How Friedman came to Britain', pp. 172-202, of W. Parsons, The Power of the Financial Press (Aldershot, UK and Brookfield, US: Edward Elgar, 1989).

18. Bank of England and HM Treasury, Cmnd. 7858 Monetary Control (London: HMSO, 1980).

19. See my pamphlet, Monetarism Lost (London: Centre for Policy Studies, 1989), for a more detailed description of the evolution of monetary policy in the 1980s.

20. Moggridge and Johnson (eds), Keynes: Tract, pp. 145-6.

21. Moggridge and Johnson (eds), Keynes: Tract, pp. 153-4. 
22. Alan Walters, Britain's Economic Renaissance (New York: Oxford University Press, 1986), pp. 116-17.

23. This is a reference to Sir John Hicks's famous paper on 'A suggestion for simplifying the theory of money', written before Keynes's General Theory.

24. Milton Friedman's 'The quantity theory of money: a restatement', a paper originally published in 1956, said that 'the demand for money is a special topic in the theory of capital'. It was the theoretical launching-pad of the so-called 'monetarist counterrevolution'.

25. Professor Patrick Minford of Liverpool University argued late into the boom that slow growth of M0 presaged an early return to 3 per cent inflation. This was not the first time that Minford had been disastrously wrong by using M0 for forecasting purposes. $\mathrm{He}$ warned in late 1985 that, because of slow M0 growth, 'we now have the tightest monetary policy we have ever had' and maintained that 'a stalling in the growth rate, unless immediate action is taken to reduce interest rates, is now increasingly likely'. See p. 45 of J. Bruce-Gardyne and others, Whither Monetarism? (London: Centre for Policy Studies, 1985). These remarks were made on the eve of the strongest boom for 15 years.

26. According to one former civil servant, even Mr Denis Healey - who as Chancellor of the Exchequer had made the announcement that introduced broad money targets - did not really believe in them. 'To ascribe paternity for the MTFS to Denis Healey seems to me to be going too far. He was described at the time as an unbelieving monetarist, meaning that he adopted monetary targets only with a view to inspiring confidence in the financial world, which did believe in them.' Leo Pliatzky, The Treasury under Mrs Thatcher (Oxford: Basil Blackwell, 1989), p. 122.

27. In any case, other European countries did not suffer the illusion that full membership of the EMS specified a complete anti-inflationary policy. They also followed domestic financial targets stated in terms of credit and/or broad money. In their regard for narrow money, it was British economic policy-makers and their advisers who had become idiosyncratic. The Bank of England stopped publishing data on M0 in early 2006. 